\title{
Sex Ratio, Body Mass, and Harvest Rates for Five Sympatric Mammalian Carnivores in the Canadian Prairies
}

\author{
SERGE LARIVIÈRE ${ }^{1,2,3}$, VANCE Lester ${ }^{2}$, and WANDA GORSUCH ${ }^{1}$ \\ ${ }^{1}$ Delta Waterfowl Foundation, R.R. \# 1 Box 1, Site 1, Portage La Prairie, Manitoba, R1N 3A1 Canada \\ ${ }^{2}$ Department of Biology, University of Saskatchewan, 112 Science Place, Saskatoon, Saskatchewan S7N 5E2 Canada \\ ${ }^{3}$ Present address: Cree Hunters and Trappers Income Security Board, 2700 Laurier, Champlain \#1100, Quebec, Quebec \\ G1V 4K5 Canada; e-mail: slariviere@osrcpc.ca
}

Larivière, Serge, Vance Lester, and Wanda Gorsuch. 2010. Sex ratio, body mass, and harvest rates for five sympatric mammalian carnivores in the Canadian prairies. Canadian Field-Naturalist 124(3): 204-208.

We assessed sex ratio, body mass, and harvest rates for 5 species of carnivores (Mammalia: Carnivora) collected in southern Saskatchewan, Canada during spring and summer 1999-2001. Overall, 647 adult carnivores were collected; captures consisted mostly of Striped Skunk (Mephitis mephitis, $50.7 \%$ of captures, $2.6 \pm 0.6 \mathrm{~kg}$ ), Raccoon (Procyon lotor; $28.3 \%$, $6.5 \pm 1.3 \mathrm{~kg}$ ), American Badger (Taxidea taxus, 8.2\%, 7.7 $\pm 1.5 \mathrm{~kg}$ ), Red Fox (Vulpes vulpes, 7.7\%, $4.6 \pm 0.6 \mathrm{~kg}$ ), and Coyote (Canis latrans, $5.1 \%, 11.0 \pm 1.5 \mathrm{~kg})$. Sex ratio (M:F) of captures was male-biased for Raccoon (2.5:1), Striped Skunk (1.7:1), but did not differ from 1:1 for American Badger (2.3:1), Coyote (1.7:1), or Red Fox (2.2:1). For both Striped Skunk and Raccoon, the temporal variation in sex ratio of captures suggests that males were more vulnerable to capture early in the spring than females. Harvest rates were highest for Striped Skunks (range 0.8-2.2 animals $/ \mathrm{km}^{2}$ ) followed by Raccoons $(0.4-$ 1.3 animals $\left./ \mathrm{km}^{2}\right)$, American Badgers (0.2-0.5 animal $\left./ \mathrm{km}^{2}\right)$, Red Foxes (0.2-0.4 animal $\left./ \mathrm{km}^{2}\right)$, and Coyotes $(0.1-0.4$ ani$\left.\mathrm{mals} / \mathrm{km}^{2}\right)$.

Key Words: American Badger, Taxidea taxus, Coyote, Canis latrans, Raccoon, Procyon lotor, Red Fox, Vulpes vulpes, Striped Skunk, Mephitis mephitis, Saskatchewan.

Programs that aim to reduce predator populations are often performed to help increase production of game animals (e.g., Garretson and Rohwer 2001). The collection of animal carcasses during these projects allows biologists to gain valuable basic information on predator morphometrics and abundance. For example, variables such as body mass and sex ratio are often hard to collect during livetrapping studies because of limited sample sizes, and the largest samples are typically obtained as a by-product of culling operations (e.g., Cavallini 1997). Similarly, removal operations may provide insights into animal abundance, with possible biases due to immigration or vulnerability to capture. Nonetheless, density estimates of many carnivorous species are unavailable for many areas where more conventional and more rigorous methods such as capture-mark-recapture or radio-telemetry have not been performed (Smallwood and Schonewald 1998).

The Prairie Pothole Region of North America extends from Alberta, Saskatchewan, and Manitoba in Canada south to Montana, North Dakota, South Dakota, Minnesota and parts of Iowa in the United States. This region constitutes the major breeding area for many species of ground-nesting ducks (Anatidae), and the reproductive success of these ground nesting ducks and many other grassland birds is limited by predation of their eggs (Böhning-Gaese et al. 1993; Hoekman et al. 2002). In most of the Prairie Pothole Region, mammalian carnivores such as Striped Skunks (Mephitis mephitis), Red Foxes (Vulpes vulpes), Raccoons (Pro- cyon lotor), American Badgers (Taxidea taxus), and Coyotes (Canis latrans) are the most important predators of duck eggs (Johnson et al. 1989). Herein, we took advantage of predator control operations performed to increase nest success of upland nesting ducks to obtain information on sex ratio, body mass and harvest rates of five sympatric species of prairie carnivores (Striped Skunk, Raccoon, Red Fox, American Badger and Coyote).

\section{Study Area}

Work was conducted ca. $75 \mathrm{~km}$ southwest of Weyburn, in the vicinity of the towns of Ceylon and Ogema in the province of Saskatchewan, Canada. Primary land use is cultivation of cereal and oil seed crops, as well as livestock production. Much of the area is cultivated annually although some small (typically $<1.3 \mathrm{~km}^{2}$ ) parcels of native grassland pasture and hay production areas are present. The area is typified by rolling hills with a high density of semi-permanent, seasonal and ephemeral wetlands. The study area lies within the grassland ecoregion of Saskatchewan where native vegetation communities are typically grassland or grassland-short shrub communities. Common native plant species in the area include several grasses (Agropyron sp., Boutleloua sp., Festuca sp., Hordeum sp., Koeleria sp., Poa sp., Stipa sp.), shrubs such as Western Snowberry (Symphoricarpos occidentalis), Rose (Rosa sp.), Silverberry (Elaeagnus communtata), and various forbs. Naturally occurring tree communities 
are rare, and most trees occur as planted shelter belts to shield farmstead and agricultural land from prevailing winds.

\section{Methods}

Each year (1999-2001), target animals were harvested in two experimental areas of $6.4 \mathrm{~km} \times 6.4 \mathrm{~km}$ $\left(41 \mathrm{~km}^{2}\right)$ for a total of six study areas (respectively named Ceylon, Edgeworth, Hardy, Kayville, Pangman, and Radville), each trapped for only one year. Composition of all areas varied slightly, but all included contiguous areas composed of $<20 \%$ native grassland or planted hayland. Study areas in each year of the study were separated by at least $6.4 \mathrm{~km}$ to reduce possibility of overlapping treatment effects among years.

On each study area, animals were harvested by professional trappers from 20 April to 1 July 1999, and from 10 March to 15 July 2000 and 2001. The intent was to remove all animals present on the study blocks, so trapping effort was extremely intensive (8 $700-$ 11000 trap-nights per site), and standard capture methods (bodygripping traps, foothold traps, and cage-type livetraps) were supplemented by opportunistic shooting, calling, and denning. Trappers recorded date of capture, species, age (juvenile or adult), sex and body mass for animals captured. In 1999, animals were not weighed so only gender, species and date of capture were recorded. Most animals were harvested before the emergence of young from natal dens, and only adults were included in analyses. All procedures were approved by the University of Saskatchewan Animal Care Committee (UCACS protocol \#20010055).

\section{Results}

A total of 647 adult carnivores were collected during 1999-2001. Of all animals captured, Striped Skunks and Raccoons represented the largest samples, with $50.7 \%$ and $28.3 \%$ of the captures, respectively. Other species consisted of American Badger (8.2\%), Red Fox (7.7\%), and Coyote (5.1\%).

Sex ratio (M:F) of captures was male-biased for Raccoon (2.5:1, $n=183$; Fisher exact test, $P<0.001)$, Striped Skunk $(1.7: 1, n=321 ; P=0.003)$, but did not differ from 1:1 for American Badger (2.3:1, $n=50$; $P=0.066)$, Red Fox $(2.2: 1, n=39 ; P=0.107)$ and Coyote $(1.7: 1, n=33 ; P=0.464)$. We examined variations in sex ratio over time for the two most commonly captured species, Striped Skunk $(n=321)$ and Raccoon ( $n=180$; date was not recorded for three animals). Sex ratio of captures varied throughout the summer for both species (Figure 1). For Striped Skunks, males dominated the captures during early spring, and the sex ratio balanced by 16-30 April, then returned to mostly males for the rest of the summer (Figure 1A). For Raccoons, no females were captured before 16 March, and males dominated the captures for all periods except 16-30 March (Figure 1B).
We obtained mass for 428 (82.4\%) of 519 adult animals captured during 2000-2001 (Table 1). There was significant sexual dimorphism in mass, with males being larger, for Striped Skunk (Student t-test, $t=-5.4$, $\mathrm{df}=201, P<0.001)$, Raccoon $(t=-3.4, \mathrm{df}=119$, $P=0.001)$, Red Fox $(t=-3.2, \mathrm{df}=34, P=0.003)$, American Badger $(t=-5.8, \mathrm{df}=28, P<0.001)$, and the difference approached significance for Coyote $(t=-1.9$, $\mathrm{df}=27, P=0.070)$. The largest dimorphism index (male mass/female mass) was observed for American Badger (1.37).

We estimated harvest rates based on the number of captures per unit area for each of 6 study areas (Table 2). Harvest rates were highest for Striped Skunks (average $\left.1.3 \mathrm{animal} / \mathrm{km}^{2}\right)$, followed by Raccoons $(0.7$ animal $/ \mathrm{km}^{2}$ ), whereas $<0.5$ animals $/ \mathrm{km}^{2}$ were captured for Red Foxes, Badgers and Coyotes (Table 2).

\section{Discussion}

Our results provide valuable morphological and ecological information. First, sex ratio of captures was male-biased for both Striped Skunks and Raccoons. The chronology in harvest of Striped Skunks and Raccoons indicate clearly the harvest was biased towards male during the early season (up to June) when the sex ratio of captures becomes more even. The temporal distribution of captures by gender supports several biological arguments regarding movements of carnivores, especially for Skunks and Raccoons. First, males typically have larger home range than females and thus may be more vulnerable to capture (Gehrt and Fritzell 1996; Larivière and Messier 1998). Second, at least for Striped Skunks, males typically are the first animals to emerge from winter dens (Wade-Smith and Verts 1982). Thus, one would predict that early spring captures would be male-biased, whereas females would become more abundant in late spring captures. This is what our data indicate, for both Skunks and Raccoons.

In our study, Striped Skunks and Raccoons were the most often captured predators. Although these estimates of abundance may not truly represent density because of possible positive bias due to immigration (especially dispersal of male Striped Skunks in June - Sargeant et al. 1982), negative biases due to trapshy animals (Gehrt and Fritzell 1996), or because of immigration of neighbours following removal of residents. Nonetheless, our harvest rates were very comparable to estimates of abundance provided for similar habitats. For example, our harvest rates for Striped Skunk (0.8-2.2 animals $\left./ \mathrm{km}^{2}\right)$ are comparable to overall density estimates for the species $\left(1.8-4.8 / \mathrm{km}^{2}-\right.$ Wade-Smith and Verts 1982), and certainly a good representation of densities observed in adjacent North Dakota (0.7-0.9/ $\mathrm{km}^{2}$ — Greenwood et al. 1985). Similarly, our estimates of abundance for American Badgers $\left(0.2-0.5 / \mathrm{km}^{2}\right)$ and Coyotes $\left(0.1-0.4 / \mathrm{km}^{2}\right)$ are also well within ranges reported in the literature (0.2-0.4 ani$\mathrm{mals} / \mathrm{km}^{2}$ for both American Badgers [Messick 1987] 

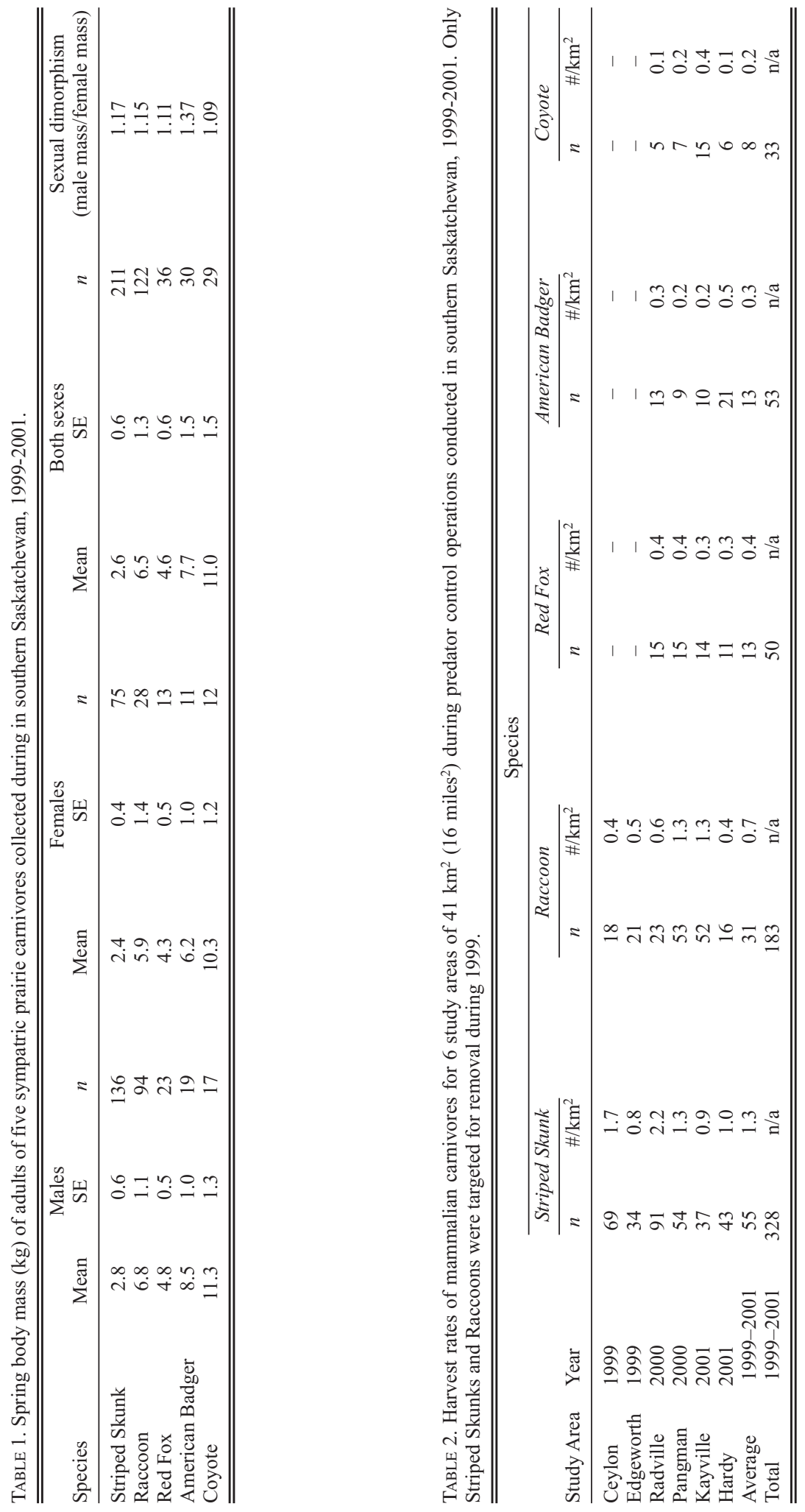


\section{A) RACCOON}

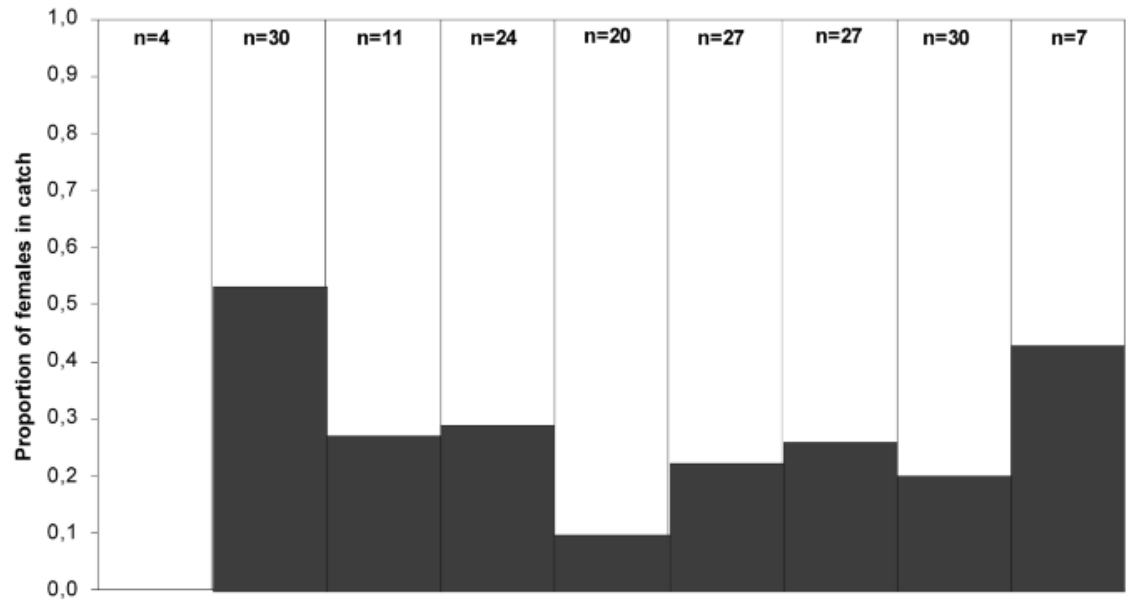

\section{B) STRIPED SKUNK}

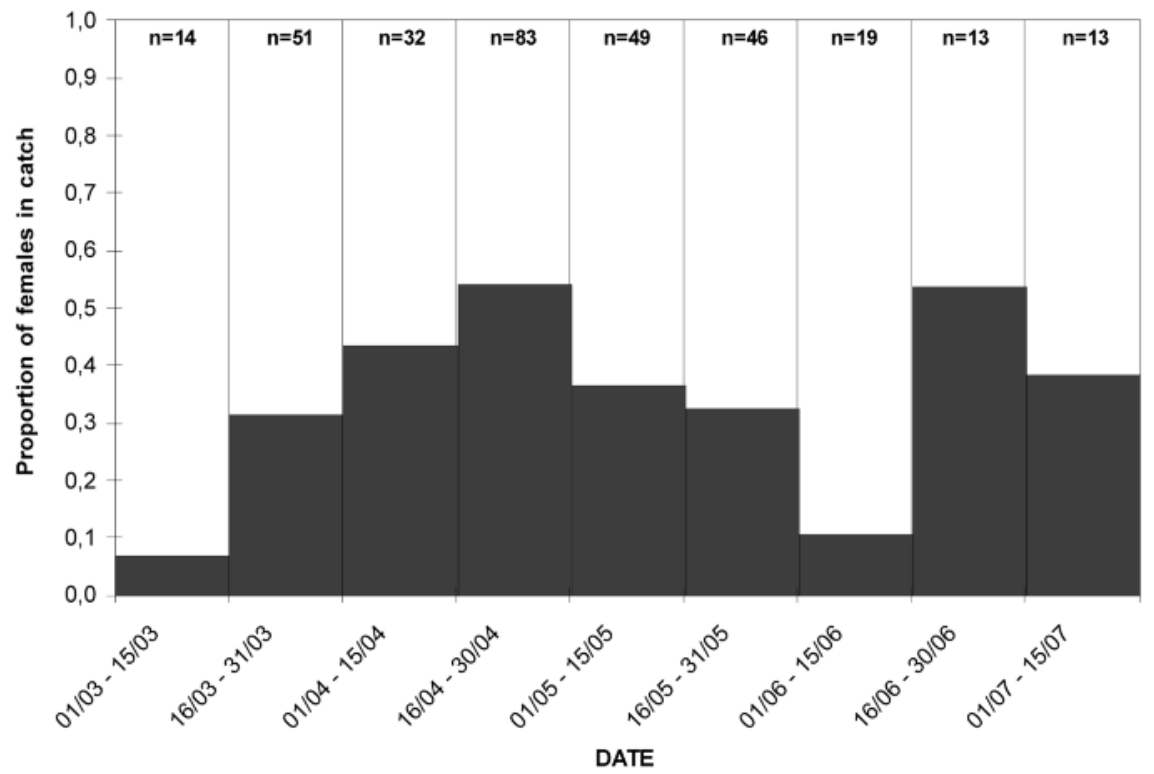

Figure. 1. Bi-weekly variation in sex ratio for A) Raccoons $(\mathrm{n}=180)$, and B) Striped Skunks $(\mathrm{n}=320)$ collected during predator control operations performed in southern Saskatchewan, 1999-2001. 
and Coyotes [Voigt and Berg 1987]). However, our harvest rates for Red Fox $\left(0.3-0.4 / \mathrm{km}^{2}\right)$ are comparable to abundance observed for Red Fox in Poland (0.4/ $\mathrm{km}^{2}$ - Goszczynski 1989), but overall lower than estimates of density for other parts of the world (typically between 1-2 animals $/ \mathrm{km}^{2}$ - Larivière and Pasistchniak-Arts 1996).

Our harvest rates for Raccoons for southern Saskatchewan are similar to density estimates in adjacent North Dakota $\left(0.5-1.0 / \mathrm{km}^{2}\right.$ - Fritzell 1978). However, these estimates are much lower than almost anywhere else in the range of the species (range 1-100 animals/ $\mathrm{km}^{2}$ - Gehrt 2002). Raccoons are a relatively new inhabitant of the prairies, and were relatively uncommon in the Canadian prairies up to 1950 (Gehrt 2002). However, Raccoons have expanded their range considerably since the turn of the century, and are now omnipresent in the Canadian prairies (Larivière 2004).

\section{Acknowledgments}

This research was funded by the Delta Waterfowl Foundation, the Institute for Wetland and Waterfowl Research of Ducks Unlimited Inc., with logistic support from the Canadian Wildlife Service. D. Gordon, B. Poncelet, and D. Paslawski conducted the trapping. M. Borgreen, F. Dillemuth, M. Eiswerth, J. Gansen, A. Hoffman, M. Kaminski, C. Michie, R. Olson, N. Wiebe, and M. Wise assisted with the field work. J. A. Pitt, Y. T. Hwang, and E. C. Hellgren reviewed earlier drafts of this manuscript.

\section{Literature Cited}

Böhning-Gaese, K., M. L. Taper, and J. H. Brown. 1993. Are declines in North American insectivorous songbirds due to causes on the breeding range? Conservation Biology 7: 76-86.

Cavallini, P. 1997. Internal organ masses of the red fox Vulpes vulpes: data from the wild. Acta Theriologica 42: 91-98.

Fritzell, E. K. 1978. Aspects of raccoon (Procyon lotor) social organization. Canadian Journal of Zoology 56: 260271.

Garretson, P. R., and F. C. Rohwer. 2001. Effects of mammalian predator removal on production of upland-nesting ducks in North Dakota. Journal of Wildlife Management 65: 398-405.

Gehrt, S. D. 2002. Raccoon. In: Wild Mammals of North America: Biology, Management, and Economics. Edited by G. A. Feldhamer, B. Thompson, and J. A. Chapman. Johns Hopkins University Press, Baltimore.

Gehrt, S. D., and E. K. Fritzell. 1996. Sex-biased responses of raccoons (Procyon lotor) to live traps. American Midland Naturalist 135: 23-32.
Goszczynski, J. 1989. Spatial distribution of red foxes Vulpes vulpes in winter. Acta Theriologica 34: 361-372.

Greenwood, R. J., A. B. Sargeant, and D. H. Johnson. 1985. Evaluation of mark-recapture for estimating striped skunk abundance. Journal of Wildlife Management 49: 332-340.

Greenwood, R. J., A. B. Sargeant, D. H. Johnson, L. M. Cowardin, and T. L. Shaffer. 1995. Factors associated with duck nest success in the Prairie Pothole Region of Canada. Wildlife Monographs 128: 1-57.

Greenwood, R. J., A. B. Sargeant, J. L. Piehl, D. A. Buhl, and B. A. Hanson. 1999. Foods and foraging of prairie striped skunks during the avian nesting season. Wildlife Society Bulletin 27: 823-832.

Hoekman, S. T., L. S. Mills, D. W. Howerter, J. H. Devries, and I. J. Ball. 2002. Sensitivity analyses of the life cycle of mid-continent mallards. Journal of Wildlife Management 66: 883-900.

Johnson, D. H., A. B. Sargeant, and R. J. Greenwood. 1989. Importance of individual species of predators on nesting success of ducks in the Canadian Prairie Pothole Region. Canadian Journal of Zoology 67: 291-297.

Larivière, S. 2004. Range expansion of raccoons in the Canadian prairies: review of hypotheses. Wildlife Society Bulletin 32: 955-963.

Larivière, S., and F. Messier. 1998. Spatial organization of a prairie striped skunk population during the waterfowl nesting season. Journal of Wildlife Management 62: 199204.

Larivière, S., and M. Pasitschniak-Arts. 1996. Vulpes vulpes. Mammalian Species 537: 1-11.

Messick, J. P. 1987. North American badger. In: Wild Furbearer Management and Conservation in North America. Edited by M. Novak, J. A. Baker, M. E. Obbard, and B. Malloch. Toronto: Ontario Ministry of Natural Resources, Canada.

Sargeant, A. B., R. J. Greenwood, J. L. Piehl, and W. B. Bicknell. 1982. Recurrence, mortality, and dispersal of prairie Striped Skunks, Mephitis mephitis, and implications to rabies epizootiology. Canadian Field-Naturalist 96: 312316.

Smallwood, K. S., and C. Schonewald. 1998. Study design and interpretation of mammalian carnivore density estimates. Oecologia 113: 474-491.

Voigt, D. R., and W. E. Berg. 1987. Coyote. Pages 345-357 in Wild Furbearer Management and Conservation in North America. Edited by M. Novak, J. A. Baker, M. E. Obbard, and B. Malloch. Toronto: Ontario Ministry of Natural Resources, Canada.

Wade-Smith, J., and B. J. Verts. 1982. Mephitis mephitis. Mammalian Species 173: 1-7.

Received 30 June 2009

Accepted 8 November 2010 